\title{
Use \& Re-Use of Water Resources in the Exploration Non-Conventional Hydrocarbons ${ }^{\dagger}$
}

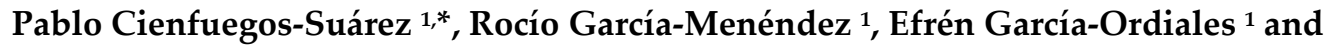 \\ Jorge Enrique Soto-Yen ${ }^{2}$ \\ 1 Department of Mining Exploitation and Prospecting, University of Oviedo, Asturias, 33004, Spain; \\ rgmgijon@gmail.com (R.G.-M.); garciaefren@uniovi.es (E.G.-O.) \\ 2 E.P. Ingeniería de minas-Facultad de Ingeniería Geológica, Minas, Metalúrgica y Geográfica, \\ Universidad Nacional Mayor de San Marcos, Cercado de Lima 15081, Peru; jsotoy@unmsm.edu.pe \\ * Correspondence: cienfuegospablo@uniovi.es; Tel.: +34-985-10-4223 \\ + Presented at the 2nd International Research Conference on Sustainable Energy, Engineering, Materials and \\ Environment (SEEME), Mieres, Spain, 25-27 September 2018.
}

Published: 2 November 2018

\begin{abstract}
The water cycle in hydraulic fracturing shows five stages that includes, from the water supply, the manufacture of the fracturing fluid, the injection, recovery of the flowback and water produced, and the management of the same. Finally, the case applied in the Asturian coal basin (ACCB) is analyzed for the development of the exploration and production of methane gas from coal layers (CBM).
\end{abstract}

Keywords: water; coalbed methane; Asturian basin

\section{Introduction}

In the current status of conventional natural gas reserves, unconventional sources such as coal layers and low permeability sandstones will be increasingly important in the future.

Both, the unconventional gas production and the hydraulic fracturing technique are not recent methods, dating the unconventional gas production to the 1800s, when the Devonian shales (Dunkirk shales) were exploited to use their natural gas to illuminate the city of Fredonia, New York; On the other hand, the first hydraulic fracturing dates from 1949 in the Hugoton oil field (Texas, USA) [1].

The production of unconventional resources, oil or gas, can change the energy market of a country, but the concerns of its environmental effects has created a problem on the progress of this industry.

Most of the environmental concerns are linked to atmospheric problems or related to the large consumption of waters, being the latter the most important concern for society.

\section{Water Management System in the Exploration and Exploitation of Non-Conventional} Hydrocarbons

There is a link between the exploitation of this resources and water, due to both are complementary and inseparable. Water is always required for the extraction of unconventional hydrocarbons.

The debate raises questions such as, where is the water needed to be extracted? Will the aquifers be contaminated during the drilling and subsequent stimulation of exploration and/or production wells? Where and how is it going to be poured the flowback water? between others. 
These questions have been answered over time. In countries such as the United States of America, Canada or Australia, where the production of unconventional hydrocarbons is, and has always been a technically and socially accepted industry, studies have continued to mitigate the potential impacts from this activity. This "know-how" is very important in countries where the exploration and production of non-conventional products is starting and allows to take advantage of the "lessons learned" from countries with a long history in this field.

The United States of America and Canada have been up to the present, the only countries where the production of these resources is an industrial activity fully integrated in the society. Fracking is a routine technique in these countries in the exploitation of unconventional resources.

In recent years, the irruption of unconventional hydrocarbons has produced an energy revolution. In 2007, production was considered null, but in 2014, with world production reaching $700 \mathrm{Bcm} /$ year for gas resources and 7.1 million barrels/day for oil (representing 20 and 8\% respectively), the search and exploration of new deposits is essential [1]. The production of hydrocarbons with hydraulic stimulation has been used in more than one million wells, reaching 600 Tcf, that correspond to the equivalent amount of 500 years of spanish consumption [2].

Is true that the volume of water necessary for exploration operations in the field of unconventional hydrocarbons is very high (between 10,000 and $30,000 \mathrm{~m}^{3}$ ) but it is equivalent to other usual activities. Thus, for example, the volume of water needed for the fracturing of a well is similar to the water needed to irrigate a golf course during a month, for operate during $12 \mathrm{~h}$ of 1000 MW power plant [3,4], or $3 \mathrm{~h}$ a $1000 \mathrm{MW}$ nuclear power plant [5].

The exploitation of unconventional resources can be an efficient industry with environmentally sustainable processes, provided that the best practices and the most appropriate technologies are used for each operation phases. Thus, in recent years, water management has been one of the main challenges for the oil and gas industry.

The production of unconventional hydrocarbons is estimated to continue increasing at least until the year 2050, with volumes up to $780 \mathrm{Bcm}$ /year for gas resources and 8.5 million barrels per day [6]). Shale gas resources are assumed to be a continuous growth, while CBM or tight gas hydrocarbons, it is believed that production will remain stable or even slightly lower in the case of the first and will increase little for the tight gas.

In this situation, one of the most important challenges is to ensure the supply of adequate and constant water for non-conventional hydrocarbon exploitation operations and, at the same time, the protection of the environment, with specially emphasis in the water resources, without interfering with the demand of water from the local community [7]. Another significant challenge for the industry is to reduce the demand for water from natural sources, studying not only alternatives to water, but also to improve treatments and water management.

The life cycle determines what stage and what processes are involved in the activity. Thus, in the case of shale gas, the life cycle includes the stages of exploration, drilling, hydraulic stimulation, production of wells and even the management of the water produced. However, some evaluations omit stages, such as exploration, processing or combustion, or do not differentiate between stages and processes. Variations make comparison difficult and prevent establishing strategies that reduce impacts.

The water cycle in hydraulic fracturing defined by the EPA [8], shows five stages that includes, from the water supply, the manufacture of the fracturing fluid, the injection, recovery of the flowback and water produced, and the management of the same. Finally, the case applied in the ACCB is analyzed for the development of the exploration and production of methane gas from coal layers (CBM).

\section{Conclusions}

The increase in the demand for gas at the international level, as a consequence of greater consumption and being a better environmental element, has led to the search for other types of gas operations in an unconventional way, which went from being unprofitable to profitable, as a consequence of the increase in prices. 
The most profitable deposits used for this type of exploitation, since they have more than more storage capacity are: Tight Gas Sand, Shale Gas, and CBM (the latter being the most possibilities can have at the time of being exploited profitably in Spain).

The industry for the extraction of hydrocarbons in unconventional deposits is a mature industry, which uses proven technologies, extensively and intensively, in the USA. Directed drilling and hydraulic fracturing have been the technologies that constitute the core of the techniques that are at the origin of the unconventional natural gas revolution.

Water management in the exploration and production of unconventional gas is a fundamental technological challenge for the success of exploration companies that face the investment risk of this type of business.

One of the factors that are showing more problematic is the possibility that the return water from hydraulic fracturing will contaminate the surface aquifers that supply drinking water. This issue should be treated with transparency and clarity so as not to weigh on future development.

The subsequent treatments of the return water are sufficiently known and commercially implanted at present in coalfields of countries like the USA.

As in the USA two of the keys to success for the development of the industry in Spain, should be: encourage exploration through tax advantages and establish an alliance with the people of the area to be an activity of which all benefit.

In Spain there are unconventional gas resources that should be explored, and in case of success all the know-how already developed could be applied. Although the Spanish sedimentary basins with unconventional gas resources have neither the extension nor the possibilities of the American basins, there are numerous "play" with possibilities of having reserves that have attracted the interest of numerous companies and has made the surface occupied by ground research permits are the largest in recent history, ensuring high exploratory activity in the coming years.

The volume of methane resources in the coal layers in Asturias is modest worldwide, but it is the largest in Spain. Given the special structure of the coal deposits, with layers with strong dips, it would be convenient to make a special research effort in exploration and exploitation with directional drilling and stimulation with hydraulic fracturing. The experiences could be extrapolated to the rest of Spain.

The Administration must react by making public forums, panels and seminars with scientists, technicians, officials and interested persons and associations to define and disseminate the "best practices" of the industry, the better understanding of the process of hydraulic fracturing and Exploration and Production (E\&P) of gas in general.

Author Contributions: P.C.-S., R.G.-M., E.G.-O. and J.E.S.-Y contributed to the design and implementation of the research, to the analysis of the results and to the writing of the manuscript.

Conflicts of Interest: The authors declare no conflict of interest. The founding sponsors had no role in the design of the study; in the collection, analyses, or interpretation of data; in the writing of the manuscript, and in the decision to publish the results.

\section{References}

1. García-Portero, J.; Stockhausen, H.; Álvarez, I. Los hidrocarburos no convencionales (HNC), pasado, presente y futuro. In Proceedings of the XIV Congreso Internacional de Energía y Recursos Minerales, Sevilla, Spain, 10-13 April 2018.

2. García-Portero, J. El gas natural no convencional. El gas natural como energía puente entre el presente energético y el deseable futuro sostenible. In Proceedings of the Congreso Nacional de. Medio Ambiente (CONAMA 2012), Madrid, Spain, 26-30 November 2012.

3. The Royal Society \& The Royal Academy of Engineering. Shale Gas Extraction in the UK: A Review of Hydraulic Fracturing; The Royal Society and The Royal Academy of Engineering: London, UK, 2012; 76p.

4. Department of Energy \& Climate Change. Fracking UK Shale: Water; Department of Energy \& Climate Change: London, UK, 2004.

5. Álvarez Pelegry, E.; Suarez Diez, C. Gas no convencional: gas shale. In Aspectos Estratégicos, Técnicos, Medioambientales y Regulatorios; Catedra Orkestra, University of Deusto, Bilbao, Spain, 2016. 
6. EIA Annual Energy Outlook 2018 with Projections to 2050. U.S. Energy Information Administration. Office of Energy Analysis. U.S. Department of Energy: Washington, DC, USA, 2018. Available online: www.eia.gov/aeo (accessed on 3 February 2018).

7. Álvarez Fernández, I.; Amores González, A.; García Blanco, T.; de Isabel García, J.A.; Vicuña Irusta, J.C. Usos del Agua en las Nuevas Tecnologías Energéticas: Hidrocarburos no Convencionales y Geotermia; Asociación Nacional de Ingenieros del ICAI y Universidad Pontificia de Comillas, Madrid, Spain, 2015; 220p, ISBN 978-84-8468-580-7.

8. EPA. Hydraulic Fracturing for Oil and Gas: Impacts from the Hydraulic Fracturing Water Cycle on Drinking Water Resources in the United States. EPA-600-R-16-236Fa; United States Environmental Protection Agency (EPA): Washington, DC, USA, 2016.

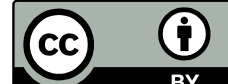

(C) 2018 by the authors. Licensee MDPI, Basel, Switzerland. This article is an open access article distributed under the terms and conditions of the Creative Commons Attribution (CC BY) license (http://creativecommons.org/licenses/by/4.0/). 